\title{
Antiangiogenic therapy for advanced renal cell carcinoma: Management of treatment-related toxicities
}

\author{
Roger B. Cohen • Stéphane Oudard
}

Received: 28 November 2011 / Accepted: 20 January 2012 /Published online: 12 February 2012

(C) The Author(s) 2012. This article is published with open access at Springerlink.com

Summary Treatment of metastatic renal cell carcinoma (mRCC) has evolved rapidly over the last two decades as major pathways involved in pathogenesis have been elucidated. These include the vascular endothelial growth factor (VEGF) axis and mammalian target of rapamycin (mTOR). Therapies targeting the VEGF pathway include bevacizumab, sorafenib, sunitinib, pazopanib, and axitinib, whereas temsirolimus and everolimus inhibit the mTOR pathway. All of these novel therapies - VEGF and mTOR inhibitors - are associated with a variety of unique toxicities, some of which may necessitate expert medical management, treatment interruption, or dose reduction. Common adverse events with newer drugs include hypertension, skin reactions, gastrointestinal disturbances, thyroid dysfunction, and fatigue. Skilled management of these toxicities is vital to ensure optimal therapeutic dosing and maximize patient outcomes, including improved survival and quality of life. This review describes and compares the toxicity profiles of novel molecularly targeted agents used in the treatment of $\mathrm{mRCC}$ and presents guidance on how best to prevent and manage treatment-related toxicities. Particular attention is given to axitinib, the newest agent to enter the armamentarium. Axitinib is a second-generation receptor tyrosine kinase inhibitor with potent VEGF receptor inhibition that provides durable

\footnotetext{
R. B. Cohen $(\bowtie)$

Division of Hematology/Oncology, University of Pennsylvania, 16 Penn Tower, 3400 Spruce Street,

Philadelphia, PA 19104, USA

e-mail: roger.cohen@uphs.upenn.edu

S. Oudard

Medical Oncology Department,

Georges Pompidou European Hospital,

20 Rue Leblanc,

Paris, France

responses and superior progression-free survival in advanced RCC compared with sorafenib.

Keywords Axitinib - Renal cell carcinoma . Tyrosine kinase inhibitor Toxicity $\cdot$ Adverse events

\section{Introduction}

The incidence of kidney cancer has been increasing worldwide, accounting for approximately $2 \%$ of all cancers (excluding non-melanoma skin cancer) [1]. In 2010, 287,421 new cases and 122,302 deaths were estimated and, by 2015, 325,433 new cases and 138,629 deaths are expected to occur [2]. Incidence and mortality rates were highest for men in more developed areas, where kidney cancer comprised $4 \%$ of all cancers [3]. Although 5-year survival rates approximate $85 \%$ for patients with localized renal cell carcinoma (RCC) (the most common type of kidney cancer), patients with advanced disease have a 5-year survival rate of only $10 \%$ [4]. Nearly half of patients with RCC eventually develop advanced disease including $30 \%$ of patients initially presenting with advanced disease and another $20-30 \%$ with early-stage disease who relapse after nephrectomy [4]. Kidney cancer subtypes include clear cell RCC $(85 \%)$ and the less common non-clear cell cancers, including papillary, collecting duct, and chromophobe RCC [5].

Chemotherapy and hormonal therapy are generally ineffective in treating kidney cancer; immunotherapy with high-dose interleukin-2 or interferon-alfa (INF- $\alpha$ ) is effective in some patients, particularly those with good performance status [6]. These agents are associated with low response rates $(<15 \%)$ and significant toxicities, which often limit their use and affect patient quality of life (QoL) [7]. 


\section{Targeted pathways in advanced RCC}

Research on the molecular pathobiology of advanced RCC has identified the vascular endothelial growth factor (VEGF)/VEGF receptor (VEGFR) axis and the phosphatidylinositol-3-kinase-protein kinase B/mammalian target of rapamycin (mTOR) pathway lying downstream (the "angiogenesis axis") as clinically relevant targets [8-10]. Transcription of vasculogenic mediators including VEGF and platelet-derived growth factor (PDGF) is promoted by stressors such as hypoxia, which is a strong signal for cancer angiogenesis. Angiogenesis in RCC is believed to be highly dependent on VEGF, due mainly to the high frequency of germline mutations in the von Hippel-Lindau (VHL) tumor suppressor gene. VHL mutations result in constitutive stabilization of the transcription factors HIF- $1 \alpha$ and HIF- $2 \alpha$, which activate VEGF genes, thereby promoting angiogenesis [11]. Approximately $40 \%$ to $60 \%$ of patients with VHL disease, an autosomal dominant familial cancer disorder, develop clear cell RCC [11-13]. VHL mutation is also associated with approximately $50 \%$ of nonhereditary (sporadic) clear cell RCC.

The VEGF/VEGFR axis plays a critical role in tumor growth and survival [9]. Inhibitors of this pathway are thought to exert their effects by inducing apoptosis, cytostasis, and restrictive effects on tumor vasculature [10]. VEGF-targeted agents include the monoclonal antibody bevacizumab which neutralizes VEGF itself, and receptor tyrosine kinase inhibitors (TKIs) such as sorafenib, sunitinib, pazopanib, and axitinib. These agents target the VEGFRs, as do additional TKIs in ongoing clinical development, with effects that extend beyond the VEGFRs [14, 15].

The new wave of US Food and Drug Administrationapproved molecularly targeted antiangiogenic agents has largely supplanted cytokines as first- and second-line therapy for metastatic RCC (mRCC). Second-generation molecularly targeted therapies in development include axitinib (a selective and highly potent VEGFR inhibitor); tivozanib and cediranib (also VEGFR inhibitors); brivanib (inhibitor of VEGFR and fibroblast growth factor receptor); motesanib (inhibitor of VEGFR, PDGF receptor, and c-Kit); XL184 (inhibitor of VEGFR-2, MET, and RET); and VEGF TRAP (novel inhibitor of VEGF-A).

Timely and appropriate management of treatmentrelated toxicities is vital in order to deliver therapy safely and optimally. This review describes and compares the toxicity profiles of antiangiogenic agents used in mRCC. Particular attention is devoted to axitinib, an antiangiogenic multi-targeted TKI in active clinical development for mRCC. Guidelines for preventing and managing treatment-related toxicities of axitinib are presented, which also have general relevance to all of the small-molecule angiogenesis inhibitors.
Efficacy of new antiangiogenic agents in pivotal clinical trials

Findings from key clinical trials of approved antiangiogenic agents (sorafenib, sunitinib, bevacizumab, and pazopanib) in advanced RCC have reported consistent prolongation of progression-free survival (PFS) and, in some cases, overall survival (OS) in both treatment-naïve and previously treated patients (Table 1).

The newer agent, axitinib, is a potent, selective, secondgeneration inhibitor of VEGFR-1, 2, and 3 with clinical antitumor activity in a variety of solid tumors [16-20]. In a recent pivotal randomized phase III trial, axitinib demonstrated statistically superior PFS compared with sorafenib, as well as a higher response rate [21]. Although many of the toxicities of axitinib are shared with those of the other TKIs, there are important differences, most notably an apparent higher incidence of hypertension. Moreover, the safety profile for axitinib is distinct from that of sorafenib. Common adverse events (AEs) more frequent with sorafenib versus axitinib were hand-foot syndrome (HFS), rash, alopecia, anemia, hypophosphatemia, hypocalcemia, and elevated lipase whereas the predominant toxicities with axitinib were hypertension, fatigue, nausea, vomiting, and hypothyroidism [21].

Axitinib first demonstrated clinical activity in patients with refractory advanced RCC in a phase II study [18], in which 52 patients with cytokine-refractory $\mathrm{mRCC}$ and clear-cell histology received axitinib $5 \mathrm{mg}$ twice daily (BID). An overall response rate of $44 \%$ was reported with a median duration of response of 23.0 months (range, 4.2-29.8 months). Median time to progression was 15.7 months (range, 8.4-23.4 months) and median OS was 29.9 months (range, 2.4-35.8 months). In a second phase II trial [19], patients with sorafenib-refractory mRCC received axitinib at a starting dose of $5 \mathrm{mg}$ BID. Axitinib produced a $23 \%$ response rate and median duration of response of 17.5 months. Median PFS was 7.4 months (95\% CI, 6.7-11.0) and median OS was 13.6 months (95\% CI, 8.4-18.8).

In the recent phase III trial in patients with advanced RCC [21], axitinib $5 \mathrm{mg}$ BID demonstrated superior PFS compared with sorafenib $400 \mathrm{mg}$ BID (6.7 versus 4.7 months; $P=0.0001)$ with a significantly higher response rate $(19.4$ versus $9.4 \% ; P=0.0001$ ) (Table 1). Patient-reported $\mathrm{QoL}$ was comparable between the two treatment arms.

\section{Toxicity profile of new antiangiogenic agents for mRCC}

Commonly reported toxicities for antiangiogenic agents in patients with $\mathrm{mRCC}$ include class effects of fatigue, asthenia, diarrhea, nausea, anorexia, rash, HFS, and hypertension (Table 2) [21-25]. Other toxicities or combinations of side 
Table 1 Overview of efficacy of targeted therapies for mRCC

\begin{tabular}{|c|c|c|c|c|c|}
\hline & $\begin{array}{l}\text { Bevacizumab } \\
+ \text { IFN- } \alpha^{\mathrm{a}}\end{array}$ & Sorafenib $^{\mathrm{b}}$ & Sunitinib $^{\mathrm{a}}$ & Pazopanib $^{\mathrm{b}}$ & Axitinib $^{a}$ \\
\hline \multicolumn{6}{|l|}{ Treatment-naïve } \\
\hline \multirow[t]{2}{*}{ Study 1} & vs IFN & vs IFN & vs IFN & vs $\mathrm{PBO}$ & \\
\hline & $N=649[23]$ & $N=189$ [79] & $N=750[43]$ & $N=435[55]$ & \\
\hline \multirow[t]{2}{*}{ PFS (mo) } & 11 vs 5 & 5.7 vs 5.6 & 11 vs 5 & 11.1 vs 2.8 & \\
\hline & $\begin{aligned} \mathrm{HR} & =0.63 ; \mathrm{CI}, 0.52-0.75 ; \\
P & =0.0001\end{aligned}$ & & $\begin{array}{c}\mathrm{HR}=0.42 ; \mathrm{CI} \\
0.32-0.54 \\
P<0.001\end{array}$ & $\begin{array}{l}\mathrm{HR}=0.46 ; \mathrm{CI} \\
\quad 0.34-0.62 ; P<0.0001\end{array}$ & \\
\hline ORR (CR + PR) & 31 vs $6 \%{ }^{\mathrm{c}}$ & 5.2 vs $8.7 \%^{\mathrm{d}}$ & $37 \% *$ & & \\
\hline \multirow[t]{2}{*}{ OS (mo) } & 23.3 vs $21.3[78]$ & $\mathrm{NR}$ & 26.4 vs $21.8[28]$ & $32 \%{ }^{\mathrm{d}} \mathrm{NR}$ & \\
\hline & $\begin{array}{l}\mathrm{HR}=0.86 ; \mathrm{CI}, 0.72-1.04 \\
\quad P<0.1291\end{array}$ & & $\begin{array}{c}\mathrm{HR}=0.821 ; \mathrm{CI} \\
\quad 0.673-1.001 \\
P=0.051\end{array}$ & & \\
\hline \multirow[t]{2}{*}{ Study 2} & vs IFN & & & OL & \\
\hline & $N=732[80]$ & & & $N=155[81]$ & \\
\hline PFS (mo) & 8.5 vs 5.2 & & & NR & \\
\hline ORR (CR + PR) & 25.5 vs 13.1 & & & $34 \%$ & \\
\hline OS (mo) & 18.3 vs $17.4[25]$ & & & NR & \\
\hline \multicolumn{6}{|l|}{ Cytokine failure } \\
\hline \multirow[t]{2}{*}{ Study 1} & vs $\mathrm{PBO}$ & vs PBO & OL & vs PBO & OL \\
\hline & $N=116[82]$ & $N=903[30]$ & $N=106[84]$ & $N=202[55]$ & $N=52[18]$ \\
\hline \multirow[t]{2}{*}{ PFS (mo) } & 4.8 vs 2.5 & 5.5 vs 2.8 & 8.3 & 7.4 vs 4.2 & 13.7 \\
\hline & & $\mathrm{HR}=0.44 ; \mathrm{CI}, 0.35-0.55 ; P<0.01$ & & & \\
\hline \multirow[t]{2}{*}{ ORR (CR + PR) } & $10 \%{ }^{\mathrm{C}}$ & $10 \%^{\mathrm{c}}$ & $44 \%^{\mathrm{c}}$ & $29 \%^{\mathrm{d}}$ & $44.2 \%{ }^{\mathrm{c}}$ \\
\hline & & & & & 29.9 \\
\hline \multirow[t]{2}{*}{ OS (mo) } & NR & 17.8 vs $14.3[83]$ & NR & NR & \\
\hline & & $\begin{aligned} \mathrm{HR} & =0.78 ; \mathrm{CI}, 0.62-0.97 ; \\
P & =0.0287\end{aligned}$ & & & \\
\hline \multirow[t]{2}{*}{ Study 2} & & & $\mathrm{OL}$ & $\mathrm{OL}$ & OL vs SOR \\
\hline & & & $N=107[85]$ & $N=31[81]$ & $N=723[21]$ \\
\hline \multirow[t]{2}{*}{ PFS (mo) } & & & 8.2 & NR & 6.7 vs 4.7 \\
\hline & & & & & $\begin{array}{l}\mathrm{HR}=0.665 ; \mathrm{CI} \\
\quad 0.522-0.812 ; P=0.0001\end{array}$ \\
\hline \multirow[t]{2}{*}{ ORR (CR + PR) } & & & $20 \%^{\mathrm{c}}$ & $37 \%$ & 19.4 vs $9.4 \%$ \\
\hline & & & & & $P=0.0001$ \\
\hline OS (mo) & & & 19.8 & NR & \\
\hline \multicolumn{6}{|l|}{ TKI failure } \\
\hline Study 1 & & & & & OL $N=62[19]$ \\
\hline PFS (mo) & & & & & 7.4 \\
\hline ORR $(\mathrm{CR}+\mathrm{PR})$ & & & & & $22.6 \%^{\mathrm{d}}$ \\
\hline OS (mo) & & & & & 13.6 \\
\hline
\end{tabular}

${ }^{a}$ Approved in the United States (Note: bevacizumab monotherapy approved only in Europe)

${ }^{\mathrm{b}}$ Approved in the United States and Europe

${ }^{\mathrm{c}}$ Investigator assessment

${ }^{\mathrm{d}}$ Independent assessment

$m R C C$ metastatic renal cell cancer, $I F N-\alpha$ interferon- $\alpha, P B O$ placebo, $P F S$ progression-free survival, $H R$ hazard ratio, $C I 95 \%$ confidence interval, $O R R$ overall response rate, $C R$ complete response, $P R$ partial response, $O S$ overall survival, $N R$ not reported, $O L$ open-label, $S O R$ sorafenib

effects appear to be relatively specific to particular antiangiogenic agents.

Toxicities across cancer populations

Toxicity profiles of antiangiogenic therapies lack disease specificity and thus can be usefully summarized and compared across disease indications. AEs reported for these agents in patients with $\mathrm{mRCC}$ are very similar to toxicities reported for sunitinib in gastrointestinal stromal tumors [22], sorafenib in hepatocellular carcinoma [24], bevacizumab monotherapy in glioblastoma, and bevacizumab plus chemotherapy for metastatic colorectal cancer, non-squamous non-small cell lung cancer, and metastatic breast cancer. 
Table 2 Toxicity profile of targeted therapies as first- and second-line treatment of mRCC

\begin{tabular}{|c|c|c|c|c|c|c|c|c|c|c|}
\hline \multirow{3}{*}{ Previous treatment status } & \multirow{2}{*}{\multicolumn{2}{|c|}{$\begin{array}{l}\text { VEGF inhibitor } \\
\text { Bevacizumab }+ \text { IFN- } \alpha \\
{[23]}\end{array}$}} & \multicolumn{8}{|c|}{ TKIs } \\
\hline & & & \multicolumn{2}{|c|}{ Sorafenib [30] } & \multicolumn{2}{|c|}{ Sunitinib [28] } & \multicolumn{2}{|c|}{ Pazopanib [55] } & \multicolumn{2}{|c|}{ Axitinib [21] } \\
\hline & \multicolumn{2}{|c|}{ Tx-naïve } & \multicolumn{2}{|c|}{ Cytokine failure } & \multicolumn{2}{|c|}{ Tx-naïve } & \multicolumn{2}{|c|}{$\begin{array}{l}\text { Tx-naïve + cytokine } \\
\text { failure }\end{array}$} & \multicolumn{2}{|c|}{$\begin{array}{l}\text { TKI + cytokine } \\
\text { failure }\end{array}$} \\
\hline \multicolumn{11}{|l|}{ Dose modification, \% patients } \\
\hline Dose reduction & \multicolumn{2}{|l|}{40} & \multicolumn{2}{|l|}{13} & \multicolumn{2}{|l|}{52} & \multicolumn{2}{|l|}{36} & \multicolumn{2}{|l|}{31} \\
\hline Dose interruption & \multicolumn{2}{|l|}{-} & \multicolumn{2}{|l|}{21} & \multicolumn{2}{|l|}{54} & \multicolumn{2}{|l|}{42} & \multicolumn{2}{|l|}{77} \\
\hline \multirow[t]{2}{*}{ AE, \% patients } & \multicolumn{10}{|c|}{ AE grade } \\
\hline & All & $3 / 4$ & All & $3 / 4$ & All & 3,4 & All & 3,4 & All & $\geq 3$ \\
\hline \multicolumn{11}{|l|}{ Cardiovascular } \\
\hline Hypertension & 26 & 3 & 17 & 4 & 30 & 12,0 & 40 & 4,0 & 40 & 16 \\
\hline Constitutional symptoms & & & & & & & & & & \\
\hline Fatigue & 33 & 12 & 37 & 5 & 54 & 11,0 & 19 & 2,0 & 39 & 11 \\
\hline Asthenia & 32 & 10 & - & - & 20 & $7,<1$ & 14 & 3,0 & 21 & 5 \\
\hline Hypothyroidism & - & - & - & - & 14 & 2,0 & $<10$ & $<1$ & 19 & $<1$ \\
\hline Cutaneous symptoms & & & & & & & & & & \\
\hline Rash & - & - & 40 & 1 & 24 & $1,<1$ & - & - & 13 & $<1$ \\
\hline Hand-foot syndrome & - & - & 30 & 6 & 29 & 9,0 & $<10$ & $<1$ & 27 & 5 \\
\hline Mucositis/stomatitis & - & - & - & - & 30 & 1,0 & $<10$ & $<1$ & 15 & 1 \\
\hline Gastrointestinal symptoms & & & & & & & & & & \\
\hline Diarrhea & 20 & 2 & 43 & 2 & 61 & 9,0 & 52 & $3,<1$ & 55 & 11 \\
\hline Nausea & - & - & 23 & $<1$ & 52 & 5,0 & 26 & $<1,0$ & 32 & 3 \\
\hline Vomiting & - & - & 16 & 1 & 31 & 4,0 & 21 & $2,<1$ & 24 & 3 \\
\hline Dyspepsia & - & - & - & - & 31 & 2,0 & - & - & - & - \\
\hline Anorexia/decreased appetite & 36 & 3 & 16 & $<1$ & 34 & 2,0 & 22 & 2,0 & 34 & 5 \\
\hline Abdominal pain & - & - & 11 & 2 & 11 & 2,0 & 11 & 2,0 & - & - \\
\hline Hemorrhage/bleeding & & & & & & & & & & \\
\hline All sites & 33 & 3 & 15 & 2 & - & - & 13 & - & - & - \\
\hline Laboratory & & & & & & & & & & \\
\hline Lymphopenia & - & - & - & 13 & - & - & 31 & $4,<1$ & 33 & 3 \\
\hline Neutropenia & 7 & 4 & - & - & - & - & 34 & $1,<1$ & 6 & 1 \\
\hline Thrombocytopenia & 6 & 2 & - & - & 68 & 8,1 & 32 & $<1,<1$ & 15 & $<1$ \\
\hline Decreased phosphorus & - & - & - & 13 & - & - & 34 & 4,0 & 13 & 2 \\
\hline Elevated lipase & - & - & 41 & 12 & 56 & 15,3 & - & - & 27 & 5 \\
\hline Anemia/decreased $\mathrm{Hb}$ & 10 & 3 & 8 & 3 & 79 & 6,2 & - & - & 35 & $<1$ \\
\hline Proteinuria & 18 & 7 & - & - & - & - & $<10$ & $<1$ & - & - \\
\hline
\end{tabular}

$m R C C$ metastatic renal cell cancer, $V E G F$ vascular endothelial growth factor, $T K I$ tyrosine kinase inhibitor, $I F N-\alpha$ interferon- $\alpha, T x$ treatment, $A E$ adverse event, $H b$ hemoglobin

\section{VEGF inhibitors}

Common AEs in patients with RCC receiving bevacizumab/ INF- $\alpha$ include pyrexia, anorexia, fatigue, asthenia, bleeding, hypertension, and proteinuria [23]. Bevacizumab is also associated with increased incidence of potentially lifethreatening gastrointestinal perforations and thrombovascular events [23, 25]. A meta-analysis of 12,294 patients with a variety of solid tumors treated with bevacizumab in 17 randomized controlled trials reported that the addition of bevacizumab to other cancer therapy increased the risk of gastrointestinal perforation by 1.6- to 5.7-fold, depending on tumor type and dose [26]. In addition, a recent metaanalysis [27] of $>10,000$ patients with cancer treated with bevacizumab revealed increased incidence of treatmentrelated mortality, particularly in patients who were also receiving taxanes or platinum agents. In phase III trials of bevacizumab plus INF- $\alpha$, congestive heart failure (CHF; 
in $<1 \%$ patients) and cardiac ischemia/infarction (in $1 \%$ of patients) were reported $[23,25]$.

Specific effects of TKIs commonly include hypertension, HFS (palmoplantar erythrodysesthesia), rash, mucositis, hypothyroidism, and myelosuppression (Table 2).

Across oncology trials with sunitinib, toxicities occurring in $\geq 20 \%$ of patients included anemia, diarrhea, fatigue, nausea, asthenia, mucositis/stomatitis, vomiting, hypertension, HFS, and rash [28]. Sunitinib is also associated with myelosuppression, elevated levels of thyroid-stimulating hormone (TSH), hypothyroidism, and hepatotoxicity including liver failure. In addition, there is increased risk of CHF and decline in left ventricular ejection fraction (LVEF) in $10 \%$ of patients [29]. Prolongation of QT interval may also lead to increased risk of ventricular arrhythmias. AEs occurring in $\geq 20 \%$ of sorafenib-treated patients included rash/desquamation, diarrhea, fatigue, HFS, alopecia, and nausea [30]. Sorafenib is also associated with increased risk of life-threatening bleeding. A high frequency of intracerebral hemorrhage has been reported in sorafenib- or sunitinib-treated $\mathrm{mRCC}$ patients with brain metastases [31]. Pazopanib is associated with hypothyroidism and proteinuria, as well as having variable effects on glucose levels [32]. Pazopanib can also cause hepatotoxicity; monitoring of liver function is required and dose reduction may be necessary in patients with baseline elevation in total bilirubin and other hepatic function tests [32]. Similar associations have been observed with sorafenib, with dose reductions suggested for patients with hepatic dysfunction [33]. Hyperglycemia has been reported in $41 \%$ of pazopanibtreated versus $33 \%$ of placebo-treated patients, whereas hypoglycemia was reported in $17 \%$ of pazopanib- versus $3 \%$ of placebo-treated patients.

Toxicities of concern reported for some of the investigational TKIs include cholecystitis and gall bladder enlargement with motesanib, proteinuria with axitinib, and mucositis with XL184. There appear to be some relative safety differences across the various VEFG-inhibitor therapies, although the data must still be considered incomplete at this time. In particular, bevacizumab is associated with a low incidence of hypothyroidism, sorafenib has low cardiac toxicity compared to sunitinib, and recipients of pazopanib report less fatigue.

Proposed mechanisms of common toxicities

\section{Hypertension}

Hypertension occurs in $17 \%$ to $45 \%$ of TKI-treated patients with RCC, with grade 3 or 4 hypertension reported in 3\% to $16 \%$ of patients. Elevated blood pressure (BP) typically presents early, within 3 to 4 weeks of treatment initiation $[34,35]$. Some studies of TKI-mediated BP effects reported elevations as early as the first day [36] to first week [37] of treatment.
The exact mechanisms underlying VEGF/VEGFR inhibitor-associated hypertension remain unknown but increased $\mathrm{BP}$, a dose-dependent effect of these inhibitors, is believed to be caused by increases in vascular tone and peripheral resistance. Interestingly, emergence of hypertension with these agents, including axitinib, may serve as a biomarker for antitumor efficacy [38-40].

In the sorafenib-refractory study of axitinib [19], peripheral edema and hypertension were reported by $19.4 \%$ and $45.2 \%$ of patients, respectively. Hypertension remains the major cardiovascular-related toxicity of axitinib, reported in $51 \%$ of patients $[18,19]$. A pooled analysis of phase II studies of axitinib in mRCC [40] reported that patients with at least one diastolic $\mathrm{BP}(\mathrm{dBP})$ measurement $\geq 90 \mathrm{mmHg}$ during treatment had a significantly longer median OS compared with patients with $\mathrm{dBP}<90 \mathrm{mmHg}$ (30.1 versus 10.2 months, respectively; $P<0.001)$. Likewise, an analysis of sunitinib clinical trials in patients with mRCC [39], showed that treatment-emergent hypertension was an independent predictor of PFS and OS $(P<0.001)$. PFS was 12.5 versus 2.5 months in patients with maximal systolic $\mathrm{BP}(\mathrm{sBP}) \geq 140 \mathrm{mmHg}$ versus $<140 \mathrm{mmHg}$, respectively $(P<0.001)$. Similarly, significant clinical benefit was reported for $\mathrm{dBP} \geq 90 \mathrm{mmHg}$ compared with $<90 \mathrm{mmHg}$. Effective control of BP with antihypertensive treatment did not affect the improved clinical outcome. Currently, a randomized prospective phase II axitinib trial in patients with $\mathrm{mRCC}$ is evaluating axitinib-related $\mathrm{dBP}$ changes as a possible predictive biomarker for response (ClinicalTrials.gov identifier: NCT00835978).

Before starting TKI therapy, BP should be controlled for approximately 1 week. Hypertension should be monitored and controlled with appropriate antihypertensive agents, with weekly monitoring of BP during the first cycle and 2 to 3 weeks thereafter until a stable BP has been reached, and then monitored per standard medical practice [41]. Likewise, BP should be monitored following discontinuation of TKI therapy since BP can drop rapidly.

Patients who develop stage I hypertension $(\geq 140 /$ $90 \mathrm{mmHg}$ ) or have increases in $\mathrm{dBP} \geq 20 \mathrm{mmHg}$ from baseline should initiate antihypertensive therapy, modify the dose of the current agent for better control, or add a second antihypertensive agent [41]. In some instances, dose reduction of the TKI inhibitor can be implemented to manage TKIinduced hypertension. The major classes of antihypertensive agents, including angiotensin-converting enzyme (ACE) inhibitors, beta blockers, and calcium channel blockers, have been used to treat TKI-induced hypertension. There are no consensus recommendations, however, for the use of specific antihypertensive agents in this setting [42]. Antihypertensive agents should be individualized to suit the patient's clinical status. ACE inhibitors, for example, are preferred for patients with proteinuria, chronic kidney disease risks, or metabolic syndrome [42]. 


\section{Cutaneous reactions}

Rash, HFS, and mucositis/stomatitis are common effects of antiangiogenic agents. HFS is characterized by palmoplantar lesions in areas of friction or trauma, commonly in the hands and feet. HFS may significantly affect a patient's QoL and physical functioning and often leads to treatment modification or discontinuation $[30,43]$. The precise mechanisms causing these events are largely unknown. In a sunitinib study, skin toxicity appeared after 3 to 4 weeks of treatment and was characterized by dermal vascular modifications, scattered keratinocyte necrosis, and intra-epidermal cleavage, which may be mediated via direct anti-VEGFR and/or PDGF receptor effects on dermal endothelial cells [44].

\section{Hypothyroidism}

Antiangiogenic agents are known to affect thyroid homeostasis but the precise mechanisms are not well understood. Biochemical and clinical hypothyroidism is commonly reported in patients with RCC receiving sunitinib and sorafenib [45-47]. An increase in TSH and decreases in thyroid hormone, indicative of hypothyroidism, has been reported in sunitinib-treated patients with gastrointestinal tumors [48]. VEGFR inhibitors such as sunitinib may induce thyroiditis and hypothyroidism via a direct effect on the thyroid through inhibition of VEGFR [49]. Thyroid dysfunction may also result from regression of capillaries around thyroid follicles due to VEGFR inhibition [50]. Changes in TSH appeared to correlate with fatigue in patients receiving axitinib [51]. Therefore, thyroid-function monitoring is recommended with management of hypothyroidism following standard guidelines for levothyroxine replacement therapy [52].

\section{Fatigue}

Fatigue is experienced by $19 \%$ to $77 \%$ of patients receiving antiangiogenic agents. The most common factors contributing to fatigue in patients with cancer independent of treatment with angiogenesis inhibitors are hypothyroidism, anemia, and dehydration. Hypogonadism may also contribute to the fatigue associated with sunitinib and sorafenib [53]. Fatigue has a high impact on patient QoL and should be monitored closely, following appropriate treatment guidelines to alleviate symptoms [54].

\section{Gastrointestinal disturbance}

Gastrointestinal AEs in patients with RCC treated with antiangiogenic agents include diarrhea, nausea, and vomiting (Table 3). These AEs are usually not associated with treatment discontinuation because of successful management by standard medical interventions such as antidiarrheal medications and dietary modification.

\section{Cardiovascular toxicities}

Cardiovascular toxicities of TKIs include hypertension, peripheral edema, and cardiac dysfunction [28, 30, 55]. The rate of TKI-associated cardiovascular toxicities is not well established. Cardiac damage is manageable, provided the patients receive appropriate cardiac monitoring and treatment at the first indication of myocardial damage [56]. Monitoring for drug-related toxicities can be challenging, as symptoms such as dyspnea, chest, pain, and dizziness can be ambiguous disease indicators in patients with advanced cancer. The use of beta blockers such as carvedilol and drugs such as simvastatin has been suggested as a means to protect against TKI-induced cardiac toxicities [56]. Importantly, decline in LVEF has preceded CHF in sorafenib- and sunitinib-treated patients, mainly in those with a history of coronary artery disease. LVEF declines have been observed in patients with mRCC treated with sunitinib, but it is not known if patients with cardiac conditions have a greater chance of developing sunitinibrelated LVEF [57]. Baseline and periodic assessment of LVEF are strongly recommended for patients receiving TKI therapy. Special emphasis must be placed on monitoring for the clinical signs and symptoms of CHF. Patients with signs and symptoms of CHF should be thoroughly evaluated (including LVEF assessment) and discontinue therapy. Physicians are advised to consider carefully the cardiac risk: benefit ratio for any patient before initiating therapy with VEGF inhibitors.

\section{Proteinuria}

Proteinuria is mostly observed in patients receiving bevacizumab (Table 2). The mechanism underlying proteinuria is unclear but it may reflect a role for VEGF in normal glomerular endothelial repair [58]. Patients should be monitored for proteinuria before and after treatment. Therapy should be discontinued in patients with grade 4 proteinuria.

\section{Bleeding and wound healing}

Bleeding, including epistaxis, hematemesis, gastric bleeding, and brain hemorrhage, is associated with VEGF inhibitors and is more common with bevacizumab [59]. While bleeding is generally manageable, it can be serious and sometimes fatal. Patients with serious bleeding should not receive bevacizumab. Angiogenesis is required for wound healing and, thus, anti-VEGF agents may directly affect the healing process. Wound-healing complications, such as slow or incomplete healing following surgery, have been reported for bevacizumab and pazopanib. These events were fatal in some cases. 
Table 3 Toxicity profile of axitinib in phase II studies

\begin{tabular}{|c|c|c|c|c|c|c|c|c|c|c|}
\hline \multirow[b]{2}{*}{ Previous treatment status } & \multicolumn{2}{|c|}{$\operatorname{mRCC}[19] N=62$} & \multicolumn{2}{|c|}{$\operatorname{mRCC}[18] N=52$} & \multicolumn{2}{|c|}{ TC [16] $N=60$} & \multicolumn{2}{|c|}{ NSCLC [20] $N=32$} & \multicolumn{2}{|c|}{ Melanoma [63] $N=32$} \\
\hline & \multicolumn{2}{|c|}{ Sorafenib } & \multicolumn{2}{|c|}{ Cytokine } & \multicolumn{4}{|c|}{131 Iodine } & & \\
\hline \multirow[t]{2}{*}{$\mathrm{AE}, \%$ patients } & \multicolumn{10}{|c|}{ AE grade } \\
\hline & All & $3 / 4$ & All & $3 / 4$ & All & $\geq 3$ & All & 3 & All & $>3$ \\
\hline Fatigue & 77 & 16 & 52 & 8 & 50 & 5 & 50 & 22 & 63 & 22 \\
\hline Diarrhea & 61 & 15 & 60 & 10 & 48 & 3 & 41 & 3 & 31 & 0 \\
\hline Anorexia & 48 & 0 & 35 & 2 & 30 & 0 & 50 & 0 & - & - \\
\hline Hypertension & 45 & 16 & 58 & 14 & 28 & 12 & 22 & 9 & 44 & 6 \\
\hline Nausea & 44 & 7 & 44 & 0 & 33 & 0 & 34 & 0 & 22 & 0 \\
\hline Dyspnea & 39 & 15 & - & - & - & - & - & - & - & - \\
\hline Dysphonia & 37 & 0 & 19 & 0 & - & - & 28 & 0 & 34 & 0 \\
\hline Hand-foot syndrome & 36 & 16 & 8 & - & 15 & 0 & - & - & - & 3 \\
\hline Mucosal inflammation & 34 & 2 & - & - & - & - & 16 & 0 & 16 & 0 \\
\hline Vomiting & 32 & 5 & 21 & 0 & 13 & 0 & 19 & 3 & - & - \\
\hline Weight decrease & 31 & 5 & 27 & 0 & 25 & 3 & 16 & 0 & 16 & 0 \\
\hline Cough & 29 & 0 & - & - & - & - & - & - & - & - \\
\hline Headache & 29 & 2 & 15 & 0 & 22 & 3 & - & - & - & - \\
\hline Arthralgia & 27 & 3 & 14 & 2 & - & - & 22 & 0 & 19 & 6 \\
\hline Constipation & 26 & 0 & 14 & 0 & - & - & - & - & - & - \\
\hline Dysgeusia & 23 & 0 & 12 & 0 & - & - & - & - & - & - \\
\hline Abdominal pain & 21 & 11 & 12 & 0 & - & - & - & - & - & - \\
\hline Pain in extremity & 21 & 3 & 19 & 4 & - & - & - & - & 16 & 0 \\
\hline Stomatitis & - & - & 17 & 2 & 25 & 0 & - & - & 16 & 3 \\
\hline Proteinuria & - & - & 8 & 0 & 18 & 5 & - & - & 38 & 3 \\
\hline Rash & - & - & - & - & 15 & 0 & 16 & 0 & - & - \\
\hline
\end{tabular}

$m R C C$ metastatic renal cell cancer, $T C$ thyroid cancer, NSCLC non-small cell lung cancer, $A E$ adverse event

\section{Thromboembolic events}

Angiogenesis inhibition, as well as cytotoxic chemotherapy, is associated with increased risk of both arterial thromboembolic events (ATE) and venous thromboembolic events (VTE) [60]. Several factors related to VEGF inhibition are believed to contribute to the increased risk of ATE and VTE, including the role of VEGF in the regeneration of endothelial cells. A pooled analysis of clinical trials, including trials in mRCC, reported that bevacizumab was significantly associated with an increased risk of developing VTE in patients with cancer [61]. In this analysis, the incidence of allgrade and high-grade VTE was $11.9 \%$ and $6.3 \%$, respectively. A recent meta-analysis to assess the risk of ATE reported that treatment with sunitinib and sorafenib is associated with a three-fold increase in the risk of ATE, with an overall incidence of $1.3 \%$ in patients with RCC [62]. Myocardial infarction and cardiac ischemia have also been reported for sunitinib and sorafenib.

\section{Follow-up}

Careful evaluation and follow-up of reported toxicities and their response to management often allow patients to continue treatment safely on the prescribed effective doses of antiangiogenic agents. AEs leading to dose interruption or reduction should be closely monitored so therapy can be reinstituted once side effects improve or resolve.

\section{Axitinib}

Axitinib-related toxicities in advanced RCC

\section{Common toxicities}

AEs associated with axitinib including a higher incidence of hypertension compared with some of the other TKIs, generally respond to supportive measures and dose modifications. 
The most common axitinib-related AEs reported across phase II trials [16, 18-20, 63] were fatigue, diarrhea, hypertension, and anorexia (Table 3 ). The most common grade 3/4 AEs were hypertension, fatigue, and diarrhea. The most commonly reported hematologic AE was grade $1 / 2$ anemia, which did not require dose reduction or interruption [18, 20].

In the phase III study of axitinib versus sorafenib [21], common AEs more frequently reported with sorafenib versus axitinib, respectively, included anemia (52\% versus $35 \%)$, HFS (51\% versus $27 \%)$, rash $(32 \%$ versus $13 \%)$, and alopecia (32\% versus $4 \%$ ) and AEs more frequently occurring with axitinib versus sorafenib, respectively, included hypertension ( $40 \%$ versus $29 \%$ ), fatigue (39\% versus $32 \%$ ), nausea $(32 \%$ versus $22 \%$ ), vomiting ( $24 \%$ versus $17 \%$ ), and hypothyroidism (19\% versus $8 \%$ ). The incidence of diarrhea was similar for axitinib and sorafenib $(55 \%$ and $53 \%$, respectively). Axitinib does not appear to cause neutropenia and thrombocytopenia, which have been reported with sunitinib.

Axitinib toxicities are very similar and manageable in patients with cancers other than RCC. For example, in the phase II study of axitinib in 60 patients with advanced thyroid cancer refractory to conventional therapy, grade $\geq 3$ treatment-related AEs were hypertension (12\%), fatigue $(5 \%)$, proteinuria $(5 \%)$, and diarrhea, headache, and weight decrease (3\% each) [16].

\section{Dose-limiting toxicities}

Dose-limiting AEs leading to axitinib dose reduction or interruption include hypertension, fatigue, and diarrhea. In a phase I study of patients receiving 5 to $30 \mathrm{mg}$ axitinib BID [64], hypertension was the primary doselimiting toxicity. One patient receiving axitinib $(20 \mathrm{mg}$ BID reduced to $10 \mathrm{mg}$ BID) died acutely with grade 4 hemoptysis. In patients receiving the recommended phase II 5-mg BID dose, dose-limiting toxicities were grade 2 stomatitis and grade 3 diarrhea $(n=1$ each). In phase II studies [18, 19], common AEs leading to axitinib dose interruption were dyspnea, nausea, fatigue, hypertension, and vomiting. In the sorafenib-refractory mRCC study with axitinib [19], AEs led to study discontinuation in $19 \%$ of patients and to temporary dose interruptions or reductions in $73 \%$ and $45 \%$ of patients, respectively. In the cytokine-refractory mRCC study of axitinib [18], 15 patients $(28.8 \%)$ had a dose reduction due to AEs. Dose reduction was required for grade 3 diarrhea and fatigue ( $n=2$ each); gastrointestinal upset, dehydration, myalgia, and gout ( $n=1$ each); and grade 2 hypertension $(n=7)$. In this latter study, some patients took axitinib continuously for up to 5 years without evidence for cumulative toxicities.
Management of axitinib-related toxicities in advanced RCC

\section{Assessments and monitoring of toxicities}

Pretreatment assessment should be performed with particular attention to the presence of comorbidities (e.g., preexisting hypertension) that may indicate more frequent monitoring and anticipation of possible dose reductions. Patients with preexisting cardiovascular dysfunction and cardiac risk factors should be monitored regularly with BP assessment at baseline and during treatment. Thyroid profiles should be assessed at baseline and every 2 to 3 months after initiation of therapy [65]. Very rarely, high hematocrits have been seen with axitinib $[18,66]$ and should be treated appropriately.

\section{Management of common axitinib toxicities}

Prevention and management strategies for axitinib-related AEs are presented in Table 4 and discussed below.

\section{Fatigue}

Fatigue (all grades) with axitinib treatment occurs in 39\% of patients [21]. Treatment of fatigue is supportive in nature, requiring a thorough assessment of other possible exacerbating factors (e.g., sleep disturbance, comorbid conditions, concomitant medications, hypothyroidism, or anemia). Supportive strategies include a range of approaches, from decreasing energy expenditure to psychosocial interventions. Pharmacologic strategies include treating contributing factors (e.g., anemia, hypothyroidism) and the judicious use of psychostimulants, including methylphenidate and modafanil [67]. Axitinibinduced thyroid dysfunction and hypothyroidism are easily controlled by thyroid hormone replacement therapy [68].

\section{Gastrointestinal symptoms}

Over half of patients will experience axitinib-related gastrointestinal disturbances. Patients should be advised to consume frequent small meals, drink clear fluids in regular small amounts, and avoid foods or drinks that may exacerbate diarrhea (such as dairy products) [69-72]. Diarrhea can be controlled with the use of standard antidiarrheal medication and proper hydration.

\section{Hand-foot syndrome}

HFS is experienced by up to $36 \%$ of axitinib-treated patients and can be minimized by various skincare measures prior to initiating antiangiogenic therapy $[65,73]$. Although severe episodes of HFS may necessitate dose alterations, topical treatments and avoidance of friction, especially in the feet, may provide some relief. In one study, patients treated with 
Table 4 Prevention and management axitinib-related adverse events

\begin{tabular}{|c|c|c|c|}
\hline & Prevention & Grade $\geq 1$ & Grade 3 or 4 \\
\hline \multicolumn{4}{|l|}{ Skin } \\
\hline $\begin{array}{l}\text { Hand-foot syndrome } \\
{[65,73]}\end{array}$ & $\begin{array}{l}\text { Routine manicure/pedicure } \\
\text { Remove calluses with proper tools } \\
\text { Cushion pressure points and protect areas } \\
\text { Avoid constriction/friction in concerned areas } \\
\text { Use moisturizer (alcohol-free) after bathing }\end{array}$ & & $\begin{array}{l}\text { Delay or adjust dose } \\
\text { Implement topical treatment }\end{array}$ \\
\hline $\begin{array}{l}\text { Oral mucositis/ } \\
\text { stomatitis [65] }\end{array}$ & $\begin{array}{l}\text { Maintain oral hygiene } \\
\text { Use salt and baking soda mouthwash } \\
\text { Consume a soft diet }\end{array}$ & $\begin{array}{l}\text { Use mucosal-covering agents } \\
\text { Use topical lidocaine solutions } \\
\text { If oral candidiasis present: } \\
\text { use oral fluconazole or local } \\
\text { clotrimazole troche }\end{array}$ & Dose reduction or interruption \\
\hline Rash [73] & $\begin{array}{l}\text { Use moisturizer twice daily (alcohol-free) } \\
\text { Avoid abrasive clothing/detergents/shampoo } \\
\text { Avoid direct sunlight } \\
\text { Use SPF } 30 \text { lotion/clothing }\end{array}$ & Topical hydrocortisone cream $1 \%$ & $\begin{array}{l}\text { Oral prednisone } \\
\text { For grade } 4 \text {, provide referral } \\
\text { to specialist }\end{array}$ \\
\hline \multicolumn{4}{|l|}{ Gastrointestinal } \\
\hline Diarrhea [69] & $\begin{array}{l}\text { Avoid diarrhea-enhancing foods/ } \\
\text { drinks/supplements (e.g., lactose, } \\
\text { alcohol, caffeine, fiber) } \\
\text { Drink 8-10 glasses of clear liquids daily }\end{array}$ & Loperamide or diphenoxylate & Admit patient to hospital \\
\hline $\begin{array}{l}\text { Nausea/Vomiting } \\
\text { [70-72] }\end{array}$ & $\begin{array}{l}\text { Eat small meals frequently } \\
\text { Sip fluids steadily }\end{array}$ & $\begin{array}{l}\text { Metoclopramide, prochlorperazine, } \\
\text { or haloperidol; add ondansetron or } \\
\text { granisetron }\end{array}$ & \\
\hline $\begin{array}{l}\text { Anorexia [86] } \\
\text { Constitutional }\end{array}$ & & Consider megestrol acetate & \\
\hline Fatigue $[65,86]$ & $\begin{array}{l}\text { Monitor fatigue levels } \\
\text { Use energy-conserving strategies } \\
\text { Use distraction strategies }\end{array}$ & $\begin{array}{l}\text { Exclude/treat contributing conditions } \\
\text { (e.g., depression, hypothyroidism, } \\
\text { pain, anemia) } \\
\text { Provide supportive care } \\
\text { Consider psychostimulant (e.g., } \\
\text { methylphenidate, modafanil) }\end{array}$ & Dose reduction or interruption \\
\hline
\end{tabular}

$S P F$ sun protective factor

topical urea or tazarotene or a two-agent combination (e.g., urea, fluorouracil, and/or tazarotene) reported improvement in HFS symptoms resulting from TKI therapy [74].

\section{Hypertension}

Hypertension should be controlled before starting antiangiogenic therapy. $\mathrm{BP} \geq 140 / 90 \mathrm{mmHg}$ should be actively treated using standard antihypertensive medications. Reaching a target $<140 / 90 \mathrm{mmHg}$ may require different combinations of standard agents and a different BP goal may be appropriate for some patients.

For hypertensive patients with uncontrolled BP, the dose of antihypertensive medication should be increased or, if on a maximal dose, a second agent should be added and its dose increased as appropriate. At pretreatment assessment, hypertensive patients can initiate therapy with short-acting agents to quickly achieve BP control before exchanging medications for longer-acting agents. This approach allows cancer therapy to begin expeditiously. BP assessment prior to initiating therapy, every 2 weeks during the first 3 months of therapy, and monthly thereafter is recommended. Patients should also monitor their BP daily at home (prior to taking axitinib). Axitinibtreated patients with $\mathrm{sBP}>150 \mathrm{mmHg}$ or $\mathrm{dBP}>100 \mathrm{mmHg}$ or experiencing symptoms such as headache or visual disturbance indicating hypertension should promptly contact their physician for axitinib-dose modification.

\section{Drug-drug interactions}

Axitinib is primarily metabolized in the liver by the cytochrome P450 (CYP) 3A4 isozyme and to a lesser extent by CYP2C19 and CYP1A2. Less than $1 \%$ of the administered dose is excreted in the urine unchanged [64]. Both inducers and inhibitors of CYP metabolism may affect axitinib plasma exposures. Therefore, concomitant use of known potent 
Table 5 Axitinib modification for hypertension and proteinuria [19]

\begin{tabular}{|c|c|}
\hline Adverse event & Action \\
\hline \multicolumn{2}{|l|}{ Hypertension } \\
\hline $\begin{array}{l}\mathrm{sBP}>150 \mathrm{mmHg} \text { or } \mathrm{dBP}>100 \mathrm{mmHg} \\
\quad(\text { Two readings at least } 1 \mathrm{~h} \text { apart) }\end{array}$ & $\begin{array}{l}\text { Previously normotensive: Initiate anti-HTN therapy; maintain axitinib dose } \\
\text { Previously HTN: Increase dose of anti-HTN therapy; if already on maximal } \\
\text { dose, reduce axitinib dose by one level }\end{array}$ \\
\hline $\begin{array}{l}\mathrm{sBP}>160 \mathrm{mmHg} \text { or } \mathrm{dBP}>105 \mathrm{mmHg} \\
\quad(\text { Two readings at least } 1 \mathrm{~h} \text { apart) }\end{array}$ & $\begin{array}{l}\text { Interrupt axitinib treatment }{ }^{\mathrm{a}} \text {; adjust dose of anti-HTN agents until BP } \\
\quad<150 / 100 \mathrm{mmHg} \text {; immediately restart axitinib treatment at one lower-dose level }\end{array}$ \\
\hline $\begin{array}{l}\text { Recurrent following dose reduction } \\
\text { (Two readings at least } 1 \mathrm{~h} \text { apart) } \\
\text { Proteinuria }\end{array}$ & Reduce axitinib dose further by one level \\
\hline Proteinuria $>1 \mathrm{~g} / 24 \mathrm{~h}$ & Perform 24-h urine collection; continue axitinib dose while awaiting test results \\
\hline Proteinuria $\geq 2 \mathrm{~g} / 24 \mathrm{~h}$ & $\begin{array}{l}\text { Interrupt axitinib treatment; wait until daily protein excretion is }<2 \mathrm{~g} \text {; restart } \\
\text { axitinib treatment at a same dose or reduce by one dose level }\end{array}$ \\
\hline
\end{tabular}

${ }^{\text {a }}$ Patients should be closely monitored for the development of hypotension

$s B P$ systolic blood pressure, $d B P$ diastolic blood pressure, $H T N$ hypertensive, $B P$ blood pressure

CYP3A4 inhibitors (i.e., grapefruit juice, verapamil, ketoconazole, miconazole, erythromycin, telithromycin, clarithromycin), as well as CYP3A4 or CYP1A2 inducers (e.g., carbamazepine, dexamethasone, phenobarbital, phenytoin), should be avoided in patients receiving axitinib. Combination therapies with agents such as 5-fluorouracil, cisplatin, carboplatin, docetaxel, and paclitaxel did not affect the pharmacokinetic profile of axitinib.

\section{Axitinib dose modification}

Dose modification or treatment interruption may be required to alleviate axitinib-related toxicities. Stepwise increases from the starting dose (5 mg BID) to $7 \mathrm{mg}$ BID and then $10 \mathrm{mg}$ BID may be instituted at 2-week intervals in the absence of grade $\geq 3$ AEs or the development of hypertension. The benefit of titrating to higher doses is supported by preliminary data in RCC in which higher plasma axitinib exposure was associated with improved outcomes [75, 76]. Dose reductions are also implemented in a stepwise fashion. Thus, $5 \mathrm{mg}$ BID is reduced to $3 \mathrm{mg}$ BID, and then to $2 \mathrm{mg}$ BID, if needed. Similarly, for patients receiving 7 or $10 \mathrm{mg}$ BID, stepwise reduction should be to the next lowest dose. Recommendations for dose modifications in patients who develop hypertension or proteinuria are presented in Table 5. Dose modifications for other nonhematologic and hematologic events are presented in Table 6.

\section{Conclusions}

The new generation of targeted therapies for advanced RCC offers significant benefit compared with prior approaches such as cytokines and chemotherapy. However, significant potential for a different spectrum of toxicities clearly exists with these newer agents, including those targeting angiogenesis. Class-effects such as hypertension, fatigue, and gastrointestinal disturbances are common with all the antiangiogenic agents and should be anticipated and proactively managed. Other unique but important toxicities, including hypothyroidism, proteinuria, cutaneous reactions, and hemorrhage, occur less often. The mechanisms underlying the toxicities are beginning to be revealed, but considerable research in this area is needed. This understanding could lead to new therapies with improved toxicity profiles and/or greater specificity for selected subtypes of RCC.

Emerging evidence suggests that certain adverse effects may be biomarkers for efficacy in RCC. Despite a lack of complete understanding of the underlying biological

Table 6 Axitinib dose modification by grade of adverse event ${ }^{\mathrm{a}}$

\begin{tabular}{|c|c|c|}
\hline AE grade & Type & Modification \\
\hline 1 & $\begin{array}{l}\text { Non-hematologic } \\
\text { or Hematologic }\end{array}$ & Continue same dose \\
\hline 2 & $\begin{array}{l}\text { Non-hematologic } \\
\text { or Hematologic }\end{array}$ & Continue same dose \\
\hline \multirow[t]{2}{*}{3} & Non-hematologic & Decrease dose to one lower-dose level \\
\hline & Hematologic & Continue same dose \\
\hline 4 & $\begin{array}{l}\text { Non-hematologic } \\
\text { or hematologic }^{\mathrm{b}}\end{array}$ & $\begin{array}{l}\text { Interrupt dosing; restart at one lower- } \\
\text { dose level when AE improves to } \\
\text { CTCAE grade } 2 \text { or better }\end{array}$ \\
\hline
\end{tabular}

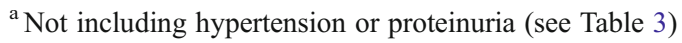

${ }^{\mathrm{b}}$ Grade 4 lymphopenia or asymptomatic biochemistry abnormality may continue without interruption

$A E$ adverse event, CTCAE Common Terminology Criteria for Adverse Events 
mechanisms, selected toxicities such as hypertension may prove to be clinically useful surrogates of response if they are reproducible and correlate well with outcomes. Ongoing pharmacogenomic research is focused on identifying specific gene polymorphisms that may be associated with increased toxicity or improved outcomes with RCC therapies.

Proper management of these AEs will ensure that patients receive optimal benefit from these newer therapies. In addition, grade 1 and 2 toxicities should not be overlooked when treating patients since these can be challenging for patients who must take drugs on a daily basis, can have substantial effects on QoL and overall healthcare costs, and may lead to treatment discontinuations. The potentially significant impact of these cumulative low-grade AEs on patients must also be weighed against the marginal clinical benefit observed with certain targeted agents in unselected patient populations. Fojo and Parkinson [77] have suggested that identification of patient subsets by use of clinically validated biomarkers, developed in parallel with new targeted therapy, may inform more biologically based patient selection. This approach offers the potential in the future of maximizing efficacy, minimizing toxicity and effects on QoL, and reducing cost.

Proactive management of these toxicities involves routine monitoring of clinical symptoms, BP, and laboratory parameters, coupled with early intervention. Active and early treatment of adverse effects is vital to maintain treatment and limit the need for dose reductions, interruptions, or discontinuations. Successful planning to anticipate the occurrence of toxicities and effective management will help ensure that patients with RCC receiving targeted therapies such as axitinib have optimal outcomes with AEs that are infrequent, lowgrade, and manageable.

Acknowledgments Editorial assistance was provided by Lynne Isbell, $\mathrm{PhD}$, and by Joseph Ramcharan, PhD, of UBC Scientific Solutions, which was funded by Pfizer Inc.

Conflict of Interest Roger Cohen serves as a paid member of a data safety and monitoring committee for a non-oncology Pfizer product. In addition, Dr. Cohen has received past funding from Pfizer for the conduct of clinical trials. These funds were paid to the Fox Chase Cancer Center. Stéphane Oudard has received honoraria from Pfizer, Novartis, Roche, and Sanofi-Aventis.

Open Access This article is distributed under the terms of the Creative Commons Attribution License which permits any use, distribution, and reproduction in any medium, provided the original author(s) and the source are credited.

\section{References}

1. Mathew A, Devesa SS, Fraumeni JF Jr, Chow WH (2002) Global increases in kidney cancer incidence, 1973-1992. Eur J Cancer Prev 11:171-178

2. Ferlay J, Shin HR, Bray F, Forman D, Mathers C, Parkin DM (2010) International Agency for Research on Cancer. The GLOBOCON Project. http://globocan.iarc.fr. Accessed 16 January 2012

3. Jemal A, Bray F, Center MM, Ferlay J, Ward E, Forman D (2011) Global cancer statistics. CA Cancer J Clin 61:69-90

4. Motzer RJ, Bander NH, Nanus DM (1996) Renal-cell carcinoma. N Engl J Med 335:865-875

5. Karumanchi SA, Merchan J, Sukhatme VP (2002) Renal cancer: molecular mechanisms and newer therapeutic options. Curr Opin Nephrol Hypertens 11:37-42

6. Yang JC, Sherry RM, Steinberg SM, Topalian SL, Schwartzentruber DJ, Hwu P, Seipp CA, Rogers-Freezer L, Morton KE, White DE, Liewehr DJ, Merino MJ, Rosenberg SA (2003) Randomized study of high-dose and low-dose interleukin-2 in patients with metastatic renal cancer. J Clin Oncol 21:3127-3132

7. Kapoor AK, Hotte SJ (2007) Current status of cytokine therapy in management of patients with metastatic renal cell carcinoma. Can Urol Assoc J 1:S28-S33

8. Rini BI (2009) Vascular endothelial growth factor-targeted therapy in metastatic renal cell carcinoma. Cancer 115:2306-2312

9. Hicklin DJ, Ellis LM (2005) Role of the vascular endothelial growth factor pathway in tumor growth and angiogenesis. J Clin Oncol 23:1011-1027

10. Ellis LM, Hicklin DJ (2008) VEGF-targeted therapy: mechanisms of anti-tumour activity. Nat Rev Cancer 8:579-591

11. Harris AL (2000) von Hippel-Lindau syndrome: target for antivascular endothelial growth factor (VEGF) receptor therapy. Oncologist 5:32-36

12. Kim JJ, Rini BI, Hansel DE (2010) Von Hippel Lindau syndrome. Adv Exp Med Biol 685:228-249

13. Schrier RW (2006) Diseases of the kidney \& urinary tract. Lippincott Williams \& Wilkins, New York

14. Cowey CL, Sonpavde G, Hutson TE (2010) New advancements and developments in treatment of renal cell carcinoma: focus on pazopanib. Onco Targets Ther 3:147-155

15. Oudard S, Ravaud A, Escudier B (2010) Sequencing of therapeutic agents in the treatment of advanced renal cell carcinoma: focus on mechanism of action. Ann Urology 1:19-27

16. Cohen EE, Rosen LS, Vokes EE, Kies MS, Forastiere AA, Worden FP, Kane MA, Sherman E, Kim S, Bycott P, Tortorici M, Shalinsky DR, Liau KF, Cohen RB (2008) Axitinib is an active treatment for all histologic subtypes of advanced thyroid cancer: results from a phase II study. J Clin Oncol 26:4708-4713

17. Rugo HS, Stopeck AT, Joy AA, Chan S, Verma S, Lluch A, Liau KF, Kim S, Bycott P, Rosbrook B, Bair AH, Soulieres D (2011) Randomized, placebo-controlled, double-blind, phase II study of axitinib plus docetaxel versus docetaxel plus placebo in patients with metastatic breast cancer. J Clin Oncol 29:2459-2465

18. Rixe O, Bukowski RM, Michaelson MD, Wilding G, Hudes GR, Bolte O, Motzer RJ, Bycott P, Liau KF, Freddo J, Trask PC, Kim S, Rini BI (2007) Axitinib treatment in patients with cytokinerefractory metastatic renal-cell cancer: a phase II study. Lancet Oncol 8:975-984

19. Rini BI, Wilding G, Hudes G, Stadler WM, Kim S, Tarazi J, Rosbrook B, Trask PC, Wood L, Dutcher JP (2009) Phase II study of axitinib in sorafenib-refractory metastatic renal cell carcinoma. J Clin Oncol 27:4462-4468

20. Schiller JH, Larson T, Ou SH, Limentani S, Sandler A, Vokes E, Kim S, Liau K, Bycott P, Olszanski AJ, von Pawel J (2009) 
Efficacy and safety of axitinib in patients with advanced nonsmall-cell lung cancer: results from a phase II study. J Clin Oncol 27:3836-3841

21. Rini BI, Escudier B, Tomczak P, Kaprin A, Szczylik C, Hutson TE, Michaelson MD, Gorbunova VA, Gore ME, Rusakov IG, Negrier S, Ou Y, Castellano D, Lim HY, Uemura H, Tarazi J, Cella D, Chen C, Rosbrook B, Kim S, Motzer RJ (2011) Comparative effectiveness of axitinib versus sorafenib in advanced renal cell carcinoma (AXIS): a randomised phase 3 trial. Lancet 378:19311939

22. Demetri GD, van Oosterom AT, Garrett CR, Blackstein ME, Shah MH, Verweij J, McArthur G, Judson IR, Heinrich MC, Morgan JA, Desai J, Fletcher CD, George S, Bello CL, Huang X, Baum CM, Casali PG (2006) Efficacy and safety of sunitinib in patients with advanced gastrointestinal stromal tumour after failure of imatinib: a randomised controlled trial. Lancet 368:1329-1338

23. Escudier B, Pluzanska A, Koralewski P, Ravaud A, Bracarda S, Szczylik C, Chevreau C, Filipek M, Melichar B, Bajetta E, Gorbunova V, Bay JO, Bodrogi I, Jagiello-Gruszfeld A, Moore N (2007) Bevacizumab plus interferon alfa-2a for treatment of metastatic renal cell carcinoma: a randomised, double-blind phase III trial. Lancet 370:2103-2111

24. Llovet JM, Ricci S, Mazzaferro V, Hilgard P, Gane E, Blanc JF, de Oliveira AC, Santoro A, Raoul JL, Forner A, Schwartz M, Porta C, Zeuzem S, Bolondi L, Greten TF, Galle PR, Seitz JF, Borbath I, Haussinger D, Giannaris T, Shan M, Moscovici M, Voliotis D, Bruix J (2008) Sorafenib in advanced hepatocellular carcinoma. N Engl J Med 359:378-390

25. Rini BI, Halabi S, Rosenberg JE, Stadler WM, Vaena DA, Archer L, Atkins JN, Picus J, Czaykowski P, Dutcher J, Small EJ (2010) Phase III trial of bevacizumab plus interferon alfa versus interferon alfa monotherapy in patients with metastatic renal cell carcinoma: final results of CALGB 90206. J Clin Oncol 28:2137-2143

26. Hapani S, Chu D, Wu S (2009) Risk of gastrointestinal perforation in patients with cancer treated with bevacizumab: a meta-analysis. Lancet Oncol 10:559-568

27. Ranpura V, Hapani S, Wu S (2011) Treatment-related mortality with bevacizumab in cancer patients: a meta-analysis. JAMA 305:487-494

28. Motzer RJ, Hutson TE, Tomczak P, Michaelson MD, Bukowski RM, Oudard S, Negrier S, Szczylik C, Pili R, Bjarnason GA, Garcia-del-Muro X, Sosman JA, Solska E, Wilding G, Thompson JA, Kim ST, Chen I, Huang X, Figlin RA (2009) Overall survival and updated results for sunitinib compared with interferon alfa in patients with metastatic renal cell carcinoma. J Clin Oncol 27:3584-3590

29. Clark JW, Eder JP, Ryan D, Lathia C, Lenz HJ (2005) Safety and pharmacokinetics of the dual action Raf kinase and vascular endothelial growth factor receptor inhibitor, BAY 43-9006, in patients with advanced, refractory solid tumors. Clin Cancer Res 11:54725480

30. Escudier B, Eisen T, Stadler WM, Szczylik C, Oudard S, Siebels M, Negrier S, Chevreau C, Solska E, Desai AA, Rolland F, Demkow T, Hutson TE, Gore M, Freeman S, Schwartz B, Shan M, Simantov R, Bukowski RM (2007) Sorafenib in advanced clear-cell renal-cell carcinoma. N Engl J Med 356:125-134

31. Pouessel D, Culine S (2008) High frequency of intracerebral hemorrhage in metastatic renal carcinoma patients with brain metastases treated with tyrosine kinase inhibitors targeting the vascular endothelial growth factor receptor. Eur Urol 53:376-381

32. Keisner SV, Shah SR (2011) Pazopanib: the newest tyrosine kinase inhibitor for the treatment of advanced or metastatic renal cell carcinoma. Drugs 71:443-454

33. Miller AA, Murry DJ, Owzar K, Hollis DR, Kennedy EB, Abou-Alfa G, Desai A, Hwang J, Villalona-Calero MA, Dees EC, Lewis LD, Fakih MG, Edelman MJ, Millard F, Frank RC, Hohl RJ, Ratain MJ
(2009) Phase I and pharmacokinetic study of sorafenib in patients with hepatic or renal dysfunction: CALGB 60301. J Clin Oncol 27:1800-1805

34. Veronese ML, Mosenkis A, Flaherty KT, Gallagher M, Stevenson JP, Townsend RR, O'Dwyer PJ (2006) Mechanisms of hypertension associated with BAY 43-9006. J Clin Oncol 24:1363-1369

35. Chu TF, Rupnick MA, Kerkela R, Dallabrida SM, Zurakowski D, Nguyen L, Woulfe K, Pravda E, Cassiola F, Desai J, George S, Morgan JA, Harris DM, Ismail NS, Chen JH, Schoen FJ, Van den Abbeele AD, Demetri GD, Force T, Chen MH (2007) Cardiotoxicity associated with tyrosine kinase inhibitor sunitinib. Lancet 370:2011-2019

36. Maitland ML, Kasza KE, Karrison T, Moshier K, Sit L, Black HR, Undevia SD, Stadler WM, Elliott WJ, Ratain MJ (2009) Ambulatory monitoring detects sorafenib-induced blood pressure elevations on the first day of treatment. Clin Cancer Res 15:6250-6257

37. Azizi M, Chedid A, Oudard S (2008) Home blood-pressure monitoring in patients receiving sunitinib. N Engl J Med 358:95-97

38. Ravaud A, Sire M (2009) Arterial hypertension and clinical benefit of sunitinib, sorafenib and bevacizumab in first and second-line treatment of metastatic renal cell cancer. Ann Oncol 20:966-967

39. Rini BI, Cohen DP, Lu DR, Chen I, Hariharan S, Gore ME, Figlin RA, Baum MS, Motzer RJ (2011) Hypertension as a biomarker of efficacy in patients with metastatic renal cell carcinoma treated with sunitinib. J Natl Cancer Inst 103:763-773

40. Rini BI, Schiller JH, Fruehauf JP, Cohen EE, Tarazi JC, Rosbrook B, Bair AH, Ricart AD, Olszanski AJ, Letrent KJ, Kim S, Rixe O (2011) Diastolic blood pressure as a biomarker of axitinib efficacy in solid tumors. Clin Cancer Res 17:3841-3849

41. Maitland ML, Bakris GL, Black HR, Chen HX, Durand JB, Elliott WJ, Ivy SP, Leier CV, Lindenfeld J, Liu G, Remick SC, Steingart R, Tang WH (2010) Initial assessment, surveillance, and management of blood pressure in patients receiving vascular endothelial growth factor signaling pathway inhibitors. J Natl Cancer Inst 102:596-604

42. Izzedine H, Ederhy S, Goldwasser F, Soria JC, Milano G, Cohen A, Khayat D, Spano JP (2009) Management of hypertension in angiogenesis inhibitor-treated patients. Ann Oncol 20:807-815

43. Motzer RJ, Hutson TE, Tomczak P, Michaelson MD, Bukowski RM, Rixe O, Oudard S, Negrier S, Szczylik C, Kim ST, Chen I, Bycott PW, Baum CM, Figlin RA (2007) Sunitinib versus interferon alfa in metastatic renal-cell carcinoma. N Engl J Med 356:115-124

44. Faivre S, Delbaldo C, Vera K, Robert C, Lozahic S, Lassau N, Bello C, Deprimo S, Brega N, Massimini G, Armand JP, Scigalla P, Raymond E (2006) Safety, pharmacokinetic, and antitumor activity of SU11248, a novel oral multitarget tyrosine kinase inhibitor, in patients with cancer. J Clin Oncol 24:25-35

45. Rini BI, Tamaskar I, Shaheen P, Salas R, Garcia J, Wood L, Reddy S, Dreicer R, Bukowski RM (2007) Hypothyroidism in patients with metastatic renal cell carcinoma treated with sunitinib. J Natl Cancer Inst 99:81-83

46. Tamaskar I, Bukowski R, Elson P, Ioachimescu AG, Wood L, Dreicer R, Mekhail T, Garcia J, Rini BI (2008) Thyroid function test abnormalities in patients with metastatic renal cell carcinoma treated with sorafenib. Ann Oncol 19:265-268

47. Miyake H, Kurahashi T, Yamanaka K, Kondo Y, Muramaki M, Takenaka A, Inoue TA, Fujisawa M (2010) Abnormalities of thyroid function in Japanese patients with metastatic renal cell carcinoma treated with sorafenib: a prospective evaluation. Urol Oncol 28:515-519

48. Desai J, Yassa L, Marqusee E, George S, Frates MC, Chen MH, Morgan JA, Dychter SS, Larsen PR, Demetri GD, Alexander EK (2006) Hypothyroidism after sunitinib treatment for patients with gastrointestinal stromal tumors. Ann Intern Med 145:660-664

49. Faris JE, Moore AF, Daniels GH (2007) Sunitinib (sutent)-induced thyrotoxicosis due to destructive thyroiditis: a case report. Thyroid 17:1147-1149 
50. Kamba T, McDonald DM (2007) Mechanisms of adverse effects of anti-VEGF therapy for cancer. Br J Cancer 96:1788-1795

51. Mukohara T, Nakajima H, Mukai H, Nagai S, Itoh K, Umeyama Y, Hashimoto J, Minami H (2010) Effect of axitinib (AG-013736) on fatigue, thyroid-stimulating hormone, and biomarkers: a phase I study in Japanese patients. Cancer Sci 101:963-968

52. Hennessey JV, Scherger JE (2007) Evaluating and treating the patient with hypothyroid disease. J Fam Pract 56:S31-S39

53. Wolter P, Wildiers H, Vanderschueren D, Dumez H, Clement $\mathrm{P}$, Schöffski P (2009) Hypogonadism in male cancer patients treated with the tyrosine kinase inhibitors sunitinib (SUN) or sorafenib (SOR). J Clin Oncol 27:abstract 3565

54. Baskin H, Cobin R, Duick D, Gharib H, Guttler R, Kaplan M, Segal R, American Association of Clinical Endocrinologists (2002) American Association of Clinical Endocrinologists medical guidelines for clinical practice for the evaluation and treatment of hyperthyroidism and hypothyroidism. Endocr Pract 8:457-469

55. Sternberg CN, Davis ID, Mardiak J, Szczylik C, Lee E, Wagstaff J, Barrios CH, Salman P, Gladkov OA, Kavina A, Zarba JJ, Chen M, McCann L, Pandite L, Roychowdhury DF, Hawkins RE (2010) Pazopanib in locally advanced or metastatic renal cell carcinoma: results of a randomized phase III trial. J Clin Oncol 28:1061-1068

56. Schmidinger M, Zielinski CC, Vogl UM, Bojic A, Bojic M, Schukro C, Ruhsam M, Hejna M, Schmidinger H (2008) Cardiac toxicity of sunitinib and sorafenib in patients with metastatic renal cell carcinoma. J Clin Oncol 26:5204-5212

57. Pfizer, Inc (2011) Highlights of prescribing information: SUTENT ${ }^{\circledR}$ (sunitinib malate) http://labeling.pfizer.com/ShowLabeling.aspx? id $=607$. Accessed 16 January 2012

58. Ostendorf T, Kunter U, Eitner F, Loos A, Regele H, Kerjaschki D, Henninger DD, Janjic N, Floege J (1999) VEGF(165) mediates glomerular endothelial repair. J Clin Invest 104:913-923

59. Gressett SM, Shah SR (2009) Intricacies of bevacizumabinduced toxicities and their management. Ann Pharmacother 43:490-501

60. Elice F, Rodeghiero F, Falanga A, Rickles FR (2009) Thrombosis associated with angiogenesis inhibitors. Best Pract Res Clin Haematol 22:115-128

61. Nalluri SR, Chu D, Keresztes R, Zhu X, Wu S (2008) Risk of venous thromboembolism with the angiogenesis inhibitor bevacizumab in cancer patients: a meta-analysis. JAMA 300:2277-2285

62. Choueiri TK, Schutz FA, Je Y, Rosenberg JE, Bellmunt J (2010) Risk of arterial thromboembolic events with sunitinib and sorafenib: a systematic review and meta-analysis of clinical trials. J Clin Oncol 28:2280-2285

63. Fruehauf JP, Lutzky J, McDermott DF, Brown CK, Pithavala YK, Bycott PW, Shalinsky D, Liau KF, Niethammer A, Rixe O (2008) Axitinib (AG-013736) in patients with metastatic melanoma: a phase II study. J Clin Oncol 26:abstract 9006

64. Rugo HS, Herbst RS, Liu G, Park JW, Kies MS, Steinfeldt HM, Pithavala YK, Reich SD, Freddo JL, Wilding G (2005) Phase I trial of the oral antiangiogenesis agent AG-013736 in patients with advanced solid tumors: pharmacokinetic and clinical results. J Clin Oncol 23:5474-5483

65. Bhojani N, Jeldres C, Patard JJ, Perrotte P, Suardi N, Hutterer G, Patenaude F, Oudard S, Karakiewicz PI (2008) Toxicities associated with the administration of sorafenib, sunitinib, and temsirolimus and their management in patients with metastatic renal cell carcinoma. Eur Urol 53:917-930

66. Alexandre I, Billemont B, Meric JB, Richard S, Rixe O (2009) Axitinib induces paradoxical erythropoietin synthesis in metastatic renal cell carcinoma. J Clin Oncol 27:472-473

67. National Comprehensive Cancer Network (2011) Cancer-related fatigue. http://www.nccn.org/professionals/physician_gls/f_guidelines. asp. Acessed 16 January 2012
68. Fujiwara Y, Kiyota N, Chayahara N, Suzuki A, Umeyama Y, Mukohara T, Minami H (2011) Management of axitinib (AG013736)-induced fatigue and thyroid dysfunction, and predictive biomarkers of axitinib exposure: results from phase I studies in Japanese patients. Invest New Drugs. doi:10.1007/s10637-0119637-1

69. Kornblau S, Benson AB, Catalano R, Champlin RE, Engelking C, Field M, Ippoliti C, Lazarus HM, Mitchell E, Rubin J, Stiff PJ, Vokes E, Wadler S (2000) Management of cancer treatment-related diarrhea. Issues and therapeutic strategies. J Pain Symptom Manage 19:118-129

70. National Cancer Institute (2011) Eating hints: before, during, and after cancer treatment. http://www.cancer.gov/cancertopics/coping/ eatinghints/page1. Accessed 16 January 2012

71. National Comprehensive Cancer Network (2011) Antiemesis. http://www.nccn.org/professionals/physician_gls/f_guidelines.asp. Accessed 16 January 2012

72. National Comprehensive Cancer Network (2011) Palliative care. http://www.nccn.org/professionals/physician_gls/f_guidelines.asp. Accessed 4 November 2011

73. Di Lorenzo G, Porta C, Bellmunt J, Sternberg CN, Kirkali Z, Staehler M, Jomiau S, Montorsi F, Buonerba C (2011) Toxicities of targeted therapy and their management in kidney cancer. Eur Urol 59:526-540

74. Lacouture ME, Reilly LM, Gerami P, Guitart J (2008) Hand foot skin reaction in cancer patients treated with the multikinase inhibitors sorafenib and sunitinib. Ann Oncol 19:19551961

75. Rixe O, Dutcher R, Motzer R, Wilding G, Stadler WM, Garrett W, Pithavala S, Kim S, Tarazi BI, Rini BI (2009) Diastolic blood pressure (dBP) and pharmacokinetics (PK) as predictors of axitinib efficacy in metastatic renal cell cancer (mRCC). J Clin Oncol 27: abstract 5045

76. Jonasch E, Bair A, Chen Y, Rini BI (2010) Axitinib with or without dose titration as first-line therapy for metastatic renal cell carcinoma (mRCC). J Clin Oncol 28:abstract TPS235

77. Fojo T, Parkinson DR (2010) Biologically targeted cancer therapy and marginal benefits: are we making too much of too little or are we achieving too little by giving too much? Clin Cancer Res 16:5972-5980

78. Escudier B, Bellmunt J, Negrier S, Bajetta E, Melichar B, Bracarda S, Ravaud A, Golding S, Jethwa S, Sneller V (2010) Phase III trial of bevacizumab plus interferon alfa-2a in patients with metastatic renal cell carcinoma (AVOREN): final analysis of overall survival. J Clin Oncol 28:2144-2150

79. Escudier B, Szczylik C, Hutson TE, Demkow T, Staehler M, Rolland F, Negrier S, Laferriere N, Scheuring UJ, Cella D, Shah S, Bukowski RM (2009) Randomized phase II trial of first-line treatment with sorafenib versus interferon Alfa-2a in patients with metastatic renal cell carcinoma. J Clin Oncol 27:1280-1289

80. Rini BI, Halabi S, Rosenberg JE, Stadler WM, Vaena DA, Ou SS, Archer L, Atkins JN, Picus J, Czaykowski P, Dutcher J, Small EJ (2008) Bevacizumab plus interferon alfa compared with interferon alfa monotherapy in patients with metastatic renal cell carcinoma: CALGB 90206. J Clin Oncol 26:54225428

81. Hutson TE, Davis ID, Machiels JP, De Souza PL, Rottey S, Hong BF, Epstein RJ, Baker KL, McCann L, Crofts T, Pandite L, Figlin RA (2010) Efficacy and safety of pazopanib in patients with metastatic renal cell carcinoma. J Clin Oncol 28:475-480

82. Yang JC, Haworth L, Sherry RM, Hwu P, Schwartzentruber DJ, Topalian SL, Steinberg SM, Chen HX, Rosenberg SA (2003) A randomized trial of bevacizumab, an anti-vascular endothelial growth factor antibody, for metastatic renal cancer. N Engl J Med 349:427-434 
83. Escudier B, Eisen T, Stadler WM, Szczylik C, Oudard S, Staehler M, Negrier S, Chevreau C, Desai AA, Rolland F, Demkow T, Hutson TE, Gore M, Anderson S, Hofilena G, Shan M, Pena C, Lathia C, Bukowski RM (2009) Sorafenib for treatment of renal cell carcinoma: Final efficacy and safety results of the phase III treatment approaches in renal cancer global evaluation trial. J Clin Oncol 27:3312-3318

84. Motzer RJ, Rini BI, Bukowski RM, Curti BD, George DJ, Hudes GR, Redman BG, Margolin KA, Merchan JR, Wilding G, Ginsberg MS, Bacik J, Kim ST, Baum CM, Michaelson MD (2006) Sunitinib in patients with metastatic renal cell carcinoma. JAMA 295:2516-2524
85. Escudier B, Roigas J, Gillessen S, Harmenberg U, Srinivas S, Mulder SF, Fountzilas G, Peschel C, Flodgren P, Maneval EC, Chen I, Vogelzang NJ (2009) Phase II study of sunitinib administered in a continuous once-daily dosing regimen in patients with cytokine-refractory metastatic renal cell carcinoma. J Clin Oncol 27:4068-4075

86. Minton O, Richardson A, Sharpe M, Hotopf M, Stone P (2008) A systematic review and meta-analysis of the pharmacological treatment of cancer-related fatigue. J Natl Cancer Inst 100:11551166 